\title{
Assessment of Acute Hepatitis C patients' Performance regarding Self-Care Management for Complications Prevention
}

\section{${ }^{1}$ Tahiya Almohammadi Mahmoud, ${ }^{2}$ Kamilia Fouad Abdallah, ${ }^{3}$ Manal Hamed Mahmoud and ${ }^{4}$ Aml Said Taha}

(1) Bachelor of Nursing, (2) Professor of Medical Surgical Nursing-Faculty of Nursing - Ain Shams University, (3) Assist. Prof. of Medical Surgical Nursing Faculty of Nursing -Benha University, and (4) Assist. Prof. of Medical Surgical Nursing Faculty of Nursing -Benha University

\begin{abstract}
Background: Hepatitis C Virus (HCV) is an important public health problem in both developed and developing countries specifically Egypt which contains the highest prevalence of hepatitis $\mathrm{C}$ in the world. The aim of this study was to assess acute hepatitis $\mathrm{C}$ patients' performance regarding self-care management for complications prevention. Research design: A descriptive research design was used. Setting: this study was conducted in hepatic department at Benha Fever Hospital. Sample: A purposive sample of 120 acute hepatitis $\mathrm{C}$ patients admitted in the previous mentioned setting. Tool: Patients' interviewing questionnaire that included the following parts; socio demographic characteristics, knowledge and self-reported practice assessment regarding self-care management. Results: More than half of studied subjects had unsatisfactory knowledge score and adequate practice score regarding self-care management. There was no statistically significant relation between patients' knowledge and their demographic data. There were statistically significant relations between patients' practice and their demographic data; marital status, educational level and gender. While, there were no statistically significant relation between patients' practice and age, residence, occupation, monthly income $\mathrm{P}>0.05$. Conclusion: Nearly two thirds of the studied subjects had unsatisfactory knowledge score regarding HCV and self-care management for complications prevention. However, more than half of them had adequate self-care management practice. The study recommended that development of health education program for $\mathrm{HCV}$ patients and their families to teach them how to apply self-care management practices for complications prevention is very important.
\end{abstract}

Key words: Acute hepatitis C, Knowledge, Practice, Self-care Management, Complications Prevention.

\section{Introduction}

Hepatitis $\mathrm{C}$ is a contagious liver disease that ranges in severity from a mild illness lasting a few weeks to a serious lifelong illness that attacks the liver, it results from infection with the hepatitis $\mathrm{C}$ virus (HCV), which is spread primarily through contact with the blood of an infected person. Hepatitis $\mathrm{C}$ can be either "acute" or "chronic". Acute $\mathrm{HCV}$ infection is a short-term illness that occurs within the first 6 months after someone is exposed to the $\mathrm{HCV}$, for most people, acute infection leads to chronic infection. Chronic $\mathrm{HCV}$ infection is a long-term illness that occurs when the HCV remains in a person's body, $\mathrm{HCV}$ infection can last a lifetime and lead to serious liver problems, including cirrhosis (scarring of the liver) or liver cancer (Thomas, 2015). 
Prevention of hepatitis $\mathrm{C}$ transmission requires a combination of harm-reduction strategies with health promotion activities such as education and communication. Effective engagement with priority populations is necessary to ensure that these strategies are tailored to best meet the needs of these groups and reach the priority populations adequately (Disease control and prevention, 2012).

Reducing the burden of HCV infection and HCV-related disease requires implementation of primary prevention activities that reduce risks for contracting $\mathrm{HCV}$ infection and secondary prevention activities that reduce risks for liver and other chronic diseases in $\mathrm{HCV}$-infected persons. In addition, surveillance and evaluation activities are required to determine the effectiveness of prevention programs in reducing incidence of disease, identifying persons infected with $\mathrm{HCV}$, providing appropriate medical followup, and promoting healthy lifestyles and behaviors (Nettleman, 2014).

The theory of self-care was developed by Orem in 1956. She pointed out that self-care activities can help individuals maintain and promote their own health. Orem understands human and environment as a unity which has mutual effect on each other. She believes that humans should care themselves independently and be responsible for their own care. For Orem, individuals can learn self-care and dependent care behaviors within a socio culture context (Dorothea, 2011).

Nurses are in a key position to carry out health education since they are the health care providers who have continuous contact with patients and their families and have the best opportunities to assess potential problems or side effect, discuss medical regimen and teach about all aspects of self-care which include maintaining physical activity, recognizing activity limitations, conserving energy, following dietary modifications and adhering to medications schedule with attention to side effects. Nursing care for patients with hepatitis $\mathrm{C}$ requires a holistic approach through which nurses help their patients meet their physical, psychological, emotional, spiritual and socioeconomic needs. Care across continuum; continuity is an essential component of all care within holistic framework (Smeltzer, et al., 2009).

\section{Significance of the study}

Hepatitis $\mathrm{C}$ is often referred to as the silent epidemic, there are about 180 million people are infected worldwide and more than 350.000 die from hepatitis C-related liver disease each year. Hepatitis $\mathrm{C}$ virus is the most common chronic blood borne infection in the United States, at least 4 million people have been exposed and 3.2 million are chronic carriers of the disease (Papafragkakis, et al., 2012).

Egypt has the highest HCV prevalence worldwide and hepatitis $\mathrm{C}$ is the most significant public health problem facing Egypt today. The prevalence rate ranges from $10 \%-20 \%$ of the general population, high rates of infection are observed among all age groups although there are regional differences in the average overall prevalence, rural population show a higher prevalence than urban ones, liver disease is a top cause of mortality in Egypt, and mathematical models predict an upsurge in cases of liver cirrhosis and liver cancer in the coming years (Hassan, et al., 2011).

\section{Subject and Method}

\section{Research design:}

A descriptive research design was used to conduct the aim of this study. 


\section{Complications Prevention}

\section{Setting:}

This study was conducted in hepatic department at Benha Fever Hospital. This department consists of two floors. Each floor contains six rooms, each room with 6 beds.

\section{Sample:}

A purposive sample of 120 patients admitted in the previous mentioned setting within three months and meeting the following criteria were recruited.

\section{Inclusion criteria:}

Patients with confirmed diagnosis of acute $\mathrm{HCV}$.

\section{Exclusion criteria:}

Patients with other associated disorders rather than acute $\mathrm{HCV}$, e.g. (hypertension, diabetis mellitus, cardiovascular disorders, renal disorders, etc......).

\section{Tools of data collection:}

Patients' interviewing questionnaire: It was developed by the investigator based on recent literature review as; Abd El Rahman, (2018), Ghazy, (2018), Abd El Salaam, (2016), Al-Metyazidy, (2014), Shata, (2014), Baghdad, (2013), Mahmoud, (2013), Ibrahim, (2012), Rizk, (2012) and Sarhan, (2011) in a simple Arabic language and included the following parts:

The first part: Patient's socio-demographic characteristics; it concerned with six items related to (age, gender, level of education, occupation, marital status, residence and monthly income).

\section{The second part:}

Patients' knowledge assessment; it was developed by the investigator. It was constructed and reviewing utilizing the most recent and relevant literature which included series of questions to elicit patients' knowledge regarding $\mathrm{HCV}$ and self-care management for complications prevention including the following:

1- Anatomy and physiology of the liver (2 questions) (2 grades).

2- HCV (2 questions) (2 grades).

3- Acute HCV (5 questions) (5 grades).

4- Diagnostic studies and laboratory investigations (3 questions) (3 grades).

5- Self-care management including the following components;

- Healthy nutrition/ dietary modifications (1 question) (1 grade).

- Exercises/ daily living activities (1 question) (1 grade).

- Prevention and healthy habits (2 questions) (2 grades).

- Therapeutic regimen and follow up (2 question) (2 grades).

6- Complications of AHCV (15 questions) (15 grades).

\section{Scoring system:}

All knowledge variables were closed ended questions. The total numbers were 33 questions; they were scored as the following.

- Each correct answer was given one grade.

- The incorrect answer was given zero.

Total score of knowledge was 33 which classified as the following:

- $\geq 70 \%$ satisfactory knowledge levelscores $\geq 23$.

- $<70 \%$ unsatisfactory knowledge levelscores $<23$.

The fourth part: Patients' self-reported practice assessment; it was developed by the investigator. It was constructed and reviewing utilizing the most recent and relevant 
literature which included series of items to elicit patients self-reported practice regarding self-care management for complications prevention including the following components:

1- Healthy nutrition/ dietary modifications (10 items) (10 grades).

2- Exercises/ daily living activities (7 items) (7 grades).

3- Healthy habits ( 8 items) (8 grades).

4- Therapeutic regimen and follow up (6 items) (6 grades).

\section{Scoring system:}

- If the patient's response to the item was yes, this item assigned a score of (1) which means adequate practice level.

- If the patients response to the item was no, this item assigned a score of (0) which means inadequate practice level.

Total score of practice was 31 which classified as the following:

- $\geq 70 \%$ adequate practice level scores $\geq 22$.

- $<70 \%$ inadequate practice level scores $<22$.

\section{Pilot study:}

Before performing the actual study, a pilot study was carried out on $10 \%$ of the study subjects to test the clarity, objectivity, feasibility and applicability of tool, as well as to estimate the time needed for data collection. It was applied on 12 patients with acute HCV. Some modifications were done to the tool based on the pilot study and opinion of experts.

\section{Validity and Reliability:}

Test face and content validity of the suggested tool by a jury of five experts in medical surgical field and necessary modification was done.
Testing reliability of proposed tool was done by Cronbach alpha test which was (0.606).

\section{Ethical considerations}

- Anonymity, confidentiality and privacy of the studied sample were assured. Voluntary participation and right to refuse to participate in the study was emphasized to the subjects.

\section{Field work and Data collection}

All patients $(n=120)$ with acute $\mathrm{HCV}$ who met the inclusion and exclusion criteria of data collection within the period from January 2018 up to the end of March 2018 included in this study. The purpose of the study was explained by the investigator to the studied patients who agreed to participate in this study. At the beginning of data collection, they were assured that the information collected would be treated confidentially and that it would be used only for the purpose of the study. The researcher visited hepatic department in the selected Hospital in the morning shift from 10 am to $1 \mathrm{pm}$ for three days weekly (Saturday, Sunday and Wednesday). Each patient was interviewed individually by the researcher using the data collection tool (Interview questionnaire sheet). The time required for filling the tool was 30 minutes for each patient, about 3 or 4 patients interviewed in each visit.

\section{Statistical analysis:}

All data collected were organized, entered and analyzed using appropriate statistical significance test. The data were collected, coded and entered to personnel computer (PC) .The data were analyzed by using SPSS, (Statistical Package for Social Sciences), soft -ware program version 20, which was applied to frequency tables, statistical significance and associations were assessed using chi-square test and coefficient 
correlation to detect the relation between the variables ( $\mathrm{P}$ value), alpha Cronbach test was used to test reliability of the tool and factor analysis to test its validity ,number and percentage, mean, range and standard deviation (SD) were also used

\section{Results:}

Table (1) shows that $81.7 \%$ of them were married, $72.5 \%$ of them were from rural area and $68.3 \%$ of study subjects had no enough monthly income. Around half of the studied subjects' $53.3 \%, 51.7 \%, 51.7 \%, 50.0 \%$, respectively their age were more than 45 years old with mean $44.2 \pm 7.86$, females and secondary educated and working at governmental sectors.

Table (2) shows that regarding anatomy and physiology of liver, $80.0 \%, 69.2 \%$ of the studied subjects' had incorrect knowledge about functions of liver and structure of liver. Regarding $\mathrm{HCV}, 78.3 \%, 71.7 \%$, and $61.7 \%$, of the studied subjects' had incorrect knowledge about meaning of acute HCV, types of $\mathrm{HCV}$, and mode of transmission of acute $\mathrm{HCV}$, respectively. Regarding laboratory investigations and self-care management, $80.0 \%, 73.3 \%, 60.8 \%$ and $60.0 \%$, respectively of them had correct knowledge about therapeutic regimen, prevention and health habits, Periodical investigations to be done and diagnostic studies to confirm acute HCV.

Table (3) shows that about half of studied subjects' (52.5\% and 50.0\%) had correct knowledge regarding high risk factors for liver cancer and complications of acute $\mathrm{HCV}$. While $80.0 \%, 75.8 \%$ of them had incorrect knowledge regarding prevention of liver cirrhosis and extra hepatic complication and more than half of them $(69.2 \%, 68.3 \%$, $66.7 \%, 65.8 \%, 65,0 \%, 61.7 \%, 60.8 \%, 57.5 \%$, $55.0 \%$ and $50.8 \%$, respectively) had incorrect knowledge regarding the following items; signs and symptoms of liver cirrhosis, symptoms of liver cancer, causes of liver cancer, causes of liver failure, prevention of liver cancer, meaning of liver cancer, causes of liver cirrhosis, meaning of liver cirrhosis, prevention of liver failure, signs and symptoms of liver failure and definition of liver failure, respectively.

Figure (1) illustrates that $(62.5 \%)$ of the studied patients had unsatisfactory knowledge score, where only (37.5\%) of them had satisfactory knowledge score.

Figure (2) shows that $68.3 \%$ of studied patients did not practice the healthy nutrition component related to self-care management, meanwhile, more than half of them performed other self-care components (healthy habits $61.7 \%$, exercise/ daily living activities $55.0 \%$, and therapeutic regimen/ follow up 55.0\%).

Figure (3) shows that $54.2 \%$ of the studied subjects had adequate practice regarding selfcare management components, while $45.8 \%$ of them had inadequate practice.

Table (4) shows that there were statistically significant relations between the studied subjects' total practice score regarding selfcare management and their socio demographic characteristics; gender $\mathrm{P}<0.001$, marital status and educational level $\mathrm{P}<0.05$.

Table (5) shows that there is statistically significant correlation between subjects' total knowledge and their total practice regarding self-care management with $\mathrm{R}=0.56$ and $\mathrm{P}<0.05$. 
Table (1): Frequency distribution of the studied subjects regarding socio-demographic characteristics $(\mathbf{n}=120)$.

\begin{tabular}{|c|c|c|}
\hline Item & $\mathrm{No}=120$ & $(\%)$ \\
\hline $\begin{array}{l}\text { Age } \\
\begin{array}{l}-23-35 \\
\quad->35 \\
-45-59 \\
\end{array}\end{array}$ & $\begin{array}{l}11 \\
45 \\
64\end{array}$ & $\begin{array}{r}9.2 \\
37.5 \\
53.3 \\
\end{array}$ \\
\hline Mean \pm SD & & \\
\hline $\begin{array}{l}\text { Gender } \\
\text { - Male } \\
\text { - Female } \\
\end{array}$ & $\begin{array}{l}58 \\
62 \\
\end{array}$ & $\begin{array}{l}48.3 \\
51.7\end{array}$ \\
\hline $\begin{array}{l}\text { Marital status } \\
\text { - Single } \\
\text { - Married } \\
\text { - Divorced } \\
\text { - Widow } \\
\end{array}$ & $\begin{array}{c}4 \\
98 \\
16 \\
2 \\
\end{array}$ & $\begin{array}{c}3.3 \\
81.7 \\
13.3 \\
1.7 \\
\end{array}$ \\
\hline $\begin{array}{l}\text { Educational level } \\
\text { - Illiterate } \\
\text { - Read \&write } \\
\text { - Secondary } \\
\text { - Highly educated } \\
\end{array}$ & $\begin{array}{l}19 \\
31 \\
62 \\
8 \\
\end{array}$ & $\begin{array}{c}15.8 \\
25.8 \\
51.7 \\
6.7 \\
\end{array}$ \\
\hline $\begin{array}{l}\text { Job } \\
\text { - Governmental sector } \\
\text { - Private sector } \\
\text { - Farmer } \\
\text { - House wife } \\
\text { - Not work }\end{array}$ & $\begin{array}{c}60 \\
15 \\
12 \\
28 \\
5\end{array}$ & $\begin{array}{c}50.0 \\
12.5 \\
10.0 \\
23.3 \\
4.2 \\
\end{array}$ \\
\hline \begin{aligned} \multicolumn{2}{l}{ Residence } \\
- $\quad$ Urban \\
- $\quad$ Rural \end{aligned} & $\begin{array}{l}33 \\
87\end{array}$ & $\begin{array}{l}27.5 \\
72.5\end{array}$ \\
\hline $\begin{array}{l}\text { Monthly income } \\
-\quad \text { Enough } \\
-\quad \text { Not enough }\end{array}$ & $\begin{array}{l}38 \\
82\end{array}$ & $\begin{array}{l}31.7 \\
68.3\end{array}$ \\
\hline
\end{tabular}


Table (2): Frequency distribution of the studied subjects regarding their knowledge about acute HCV and self-care management $(n=120)$.

\begin{tabular}{||l|c|c|c|c||}
\hline \multirow{2}{*}{\multicolumn{1}{|c|}{ Item }} & \multicolumn{2}{c|}{ Correct } & \multicolumn{2}{c||}{ Incorrect } \\
\cline { 2 - 5 } & No & \% & No & \% \\
\hline \hline Structure of liver & 37 & 30.8 & 83 & 69.2 \\
\hline Meaning of liver & 24 & 20.0 & 96 & 80.0 \\
\hline Meaning of HCV & 49 & 40.8 & 71 & 59.2 \\
\hline Types of HCV & 34 & 28.3 & 86 & 71.7 \\
\hline Definition of acute HCV & 26 & 21.7 & 94 & 78.3 \\
\hline Causes of acute HCV & 59 & 49.2 & 61 & 50.8 \\
\hline High risk group of acute HCV & 66 & 55.0 & 54 & 45.0 \\
\hline Mode of transmission of acute HCV & 46 & 38.3 & 74 & 61.7 \\
\hline Signs \& Symptoms of acute HCV & 61 & 50.8 & 59 & 49.2 \\
\hline Diagnostic studies to confirm acute HCV & 72 & 60.0 & 48 & 40.0 \\
\hline Laboratory investigations to confirm acute HCV & 49 & 40.8 & 71 & 59.2 \\
\hline Periodical investigations to be done & 73 & 60.8 & 47 & 39.2 \\
\hline Self-care management & & & & \\
Healthy nutrition/ dietary modifications & 56 & 46.7 & 64 & 53.3 \\
Exercise/ daily living activities & 41 & 34.2 & 79 & 65.8 \\
Prevention and health habits & 88 & 73.3 & 32 & 26.7 \\
Therapeutic regimen & 96 & 80.0 & 24 & 20.0 \\
\hline \hline
\end{tabular}

Table (3): Frequency distribution of the studied subjects regarding their knowledge about complications of acute $\mathrm{HCV}(\mathbf{n}=120)$

\begin{tabular}{|l|c|c|c|c|}
\hline \multirow{2}{*}{\multicolumn{1}{|c|}{ Item }} & \multicolumn{2}{c|}{ Correct } & \multicolumn{2}{c|}{ Incorrect } \\
\cline { 2 - 5 } & No & \% & No & $\%$ \\
\hline \hline Complications of acute HCV & 60 & 50.0 & 60 & 50.0 \\
\hline Meaning of liver cirrhosis & 47 & 39.2 & 73 & 60.8 \\
\hline Causes of liver cirrhosis & 46 & 38.3 & 74 & 61.7 \\
\hline Signs\& symptoms of liver cirrhosis & 36 & 30.0 & 84 & 70.0 \\
\hline Prevention of liver cirrhosis & 24 & 20.0 & 96 & 80.0 \\
\hline Meaning of liver cancer & 42 & 35.0 & 78 & 65.0 \\
\hline Causes of liver cancer & 38 & 31.7 & 82 & 68.3 \\
\hline High risk factor for liver cancer & 63 & 52.5 & 57 & 47.5 \\
\hline Symptoms of liver cancer & 37 & 30.8 & 83 & 69.2 \\
\hline Prevention of liver cancer & 41 & 34.2 & 79 & 65.8 \\
\hline Meaning of liver failure & 59 & 49.2 & 61 & 50.8 \\
\hline Causes of liver failure & 40 & 33.3 & 80 & 66.7 \\
\hline Signs\& symptoms of liver failure & 54 & 45.0 & 66 & 55.0 \\
\hline Prevention of liver failure & 51 & 42.5 & 69 & 57.5 \\
\hline Extra hepatic complications & 29 & 24.2 & 91 & 75.8 \\
\hline \hline
\end{tabular}




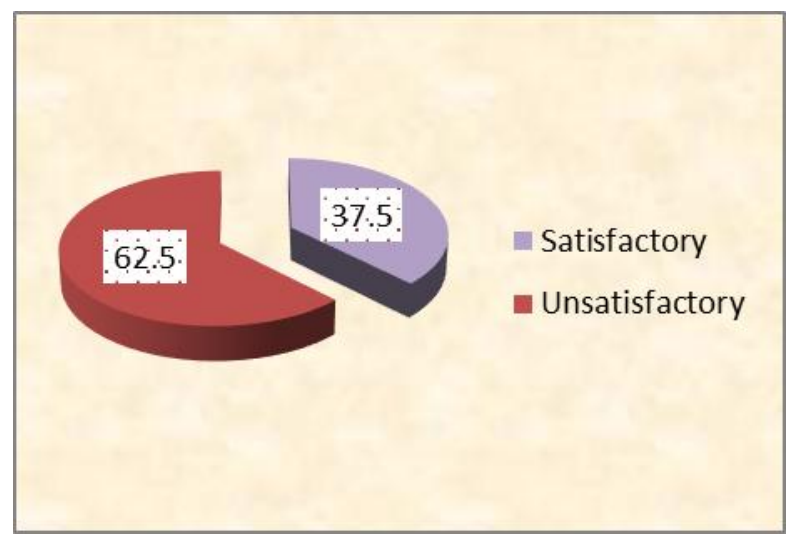

Figure (1): Frequency distribution of the studied subjects' total knowledge score regarding HCV and self-care management

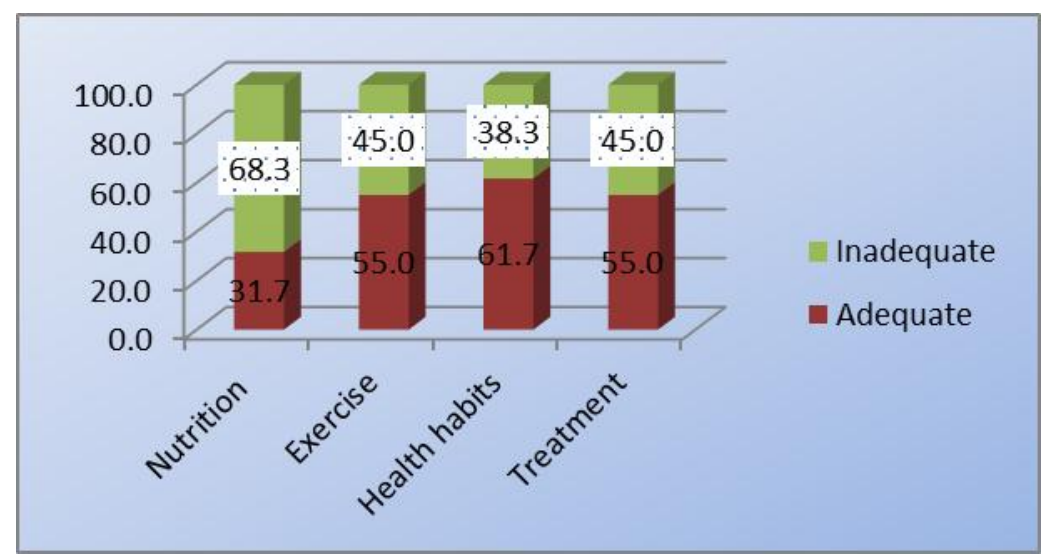

Figure (2): Frequency distribution of the studied subjects regarding self-care management components for complications prevention

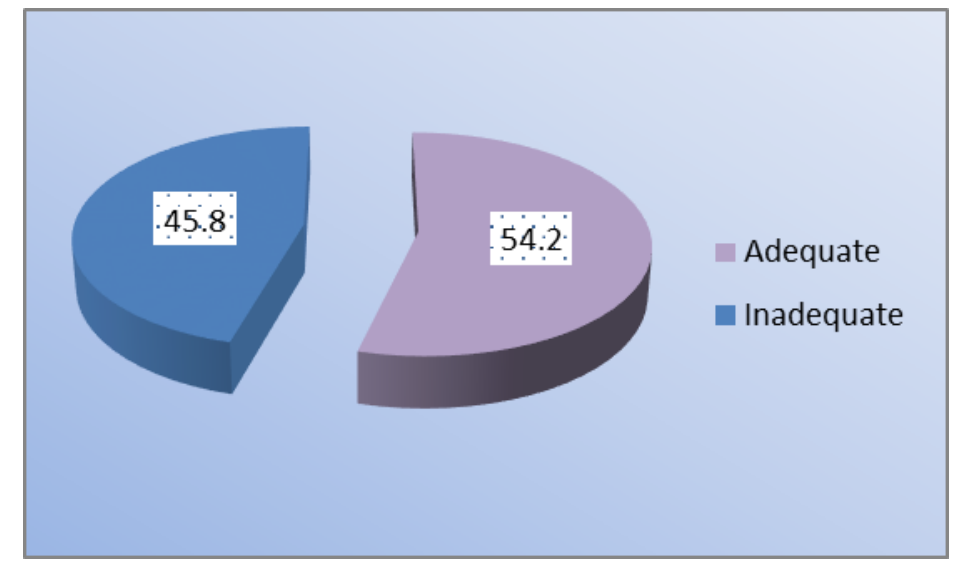

Figure (3): Frequency distribution of the studied subjects regarding their total practice level about self-care management components 
Table (4): Relations between the studied patients' total self-reported practice score regarding self-care management and their demographic characteristics $(n=120)$

\begin{tabular}{|c|c|c|c|c|c|c|}
\hline \multirow[t]{2}{*}{ Item } & \multicolumn{2}{|c|}{$\begin{array}{c}\text { Inadequate } \\
N=55\end{array}$} & \multicolumn{2}{|c|}{$\begin{array}{c}\text { Adequate } \\
N=65\end{array}$} & \multirow[t]{2}{*}{$X^{2}$} & \multirow{2}{*}{$\begin{array}{c}\mathbf{P} \\
\text { Value }\end{array}$} \\
\hline & No & $\%$ & No & $\%$ & & \\
\hline $\begin{aligned} \text { Age } & \\
- & 23-35 \\
- & >35 \\
- & 45-59\end{aligned}$ & $\begin{array}{c}8 \\
20 \\
27\end{array}$ & $\begin{array}{l}14.5 \\
36.4 \\
49.1\end{array}$ & $\begin{array}{c}3 \\
25 \\
37\end{array}$ & $\begin{array}{c}4.6 \\
38.5 \\
56.9\end{array}$ & 3.58 & 0.16 \\
\hline $\begin{array}{l}\text { Gender } \\
-\quad \text { Male } \\
-\quad \text { Female }\end{array}$ & $\begin{array}{l}38 \\
17\end{array}$ & $\begin{array}{l}69.1 \\
30.9\end{array}$ & $\begin{array}{l}20 \\
45\end{array}$ & $\begin{array}{l}30.8 \\
69.2\end{array}$ & 17.5 & $0.000 * *$ \\
\hline $\begin{array}{cl}\text { Marital status } \\
- & \text { Single } \\
- & \text { Married } \\
- & \text { Widow } \\
- & \text { Divorced }\end{array}$ & $\begin{array}{c}4 \\
46 \\
3 \\
2\end{array}$ & $\begin{array}{c}7.3 \\
83.6 \\
5.5 \\
3.6\end{array}$ & $\begin{array}{c}0 \\
52 \\
13 \\
0\end{array}$ & $\begin{array}{c}0.0 \\
80.0 \\
20.0 \\
0.0\end{array}$ & 11.86 & $0.008^{*}$ \\
\hline $\begin{array}{l}\text { Level of education } \\
-\quad \text { Illiterate } \\
-\quad \text { Read\& write } \\
-\quad \text { Secondary } \\
\text { - Highly educated }\end{array}$ & $\begin{array}{c}3 \\
18 \\
31 \\
3\end{array}$ & $\begin{array}{c}5.5 \\
32.7 \\
56.4 \\
5.5\end{array}$ & $\begin{array}{c}16 \\
13 \\
31 \\
5\end{array}$ & $\begin{array}{c}24.6 \\
20.0 \\
47.7 \\
7.7\end{array}$ & 9.43 & $0.024^{*}$ \\
\hline $\begin{aligned} \text { Job } & \\
\text { - } & \text { Governmental } \\
- & \text { Private sector } \\
- & \text { Farmer } \\
- & \text { Housewife } \\
- & \text { Not work }\end{aligned}$ & $\begin{array}{c}30 \\
10 \\
6 \\
8 \\
1\end{array}$ & $\begin{array}{c}54.5 \\
18.2 \\
10.9 \\
14.5 \\
1.8\end{array}$ & $\begin{array}{c}30 \\
5 \\
6 \\
20 \\
4\end{array}$ & $\begin{array}{c}46.2 \\
7.7 \\
9.2 \\
30.8 \\
6.2\end{array}$ & 7.83 & 0.09 \\
\hline $\begin{aligned} \text { Residence } \\
-\quad \text { Urban } \\
-\quad \text { Rural } \\
\end{aligned}$ & $\begin{array}{l}14 \\
41\end{array}$ & $\begin{array}{l}25.5 \\
74.5\end{array}$ & $\begin{array}{l}19 \\
46\end{array}$ & $\begin{array}{l}29.2 \\
70.8\end{array}$ & 0.21 & 0.64 \\
\hline $\begin{array}{c}\text { Monthly income } \\
-\quad \text { Enough } \\
-\quad \text { Not enough }\end{array}$ & $\begin{array}{l}20 \\
35\end{array}$ & $\begin{array}{l}36.4 \\
63.6\end{array}$ & $\begin{array}{l}18 \\
47\end{array}$ & $\begin{array}{l}27.7 \\
72.3\end{array}$ & 1.03 & 0.30 \\
\hline
\end{tabular}

*significant at $\mathrm{P}<0.05 * *$ High significant $\mathrm{P}<0.001$

Table (5): Correlation between the studied patients' total knowledge and practice regarding self care management score

\begin{tabular}{|l|l|l|}
\hline & Total knowledge & \\
\hline & $\mathbf{R}$ & p-value \\
\hline Total practice & $\mathbf{0 . 5 6}$ & $\mathbf{0 . 0 2 4} *$ \\
\hline
\end{tabular}

*Significant at $\mathrm{P}<0.05 * *$ Highly significant $\mathrm{P}<0.001$ 


\section{Discussion:}

The finding of present study revealed that, more than half of studied subjects were aged more than 45 years old with mean 44.2 \pm 7.86 years, this could be due to HCV is chronic disease and had decrease rate of disease progression. This finding is in accordance with Ghazy, (2018) who conducted study entitled; factors associated with self-care practices among patients with hepatitis $\mathrm{C}$ virus and stated that the majority of her studied sample was at age more than 41 years, also this finding is in accordance with Mohsen, (2009) who conducted study entitled; assessment the effect of nursing management protocol on selected side effects of Interferon and Ribavirin among hepatitis $\mathrm{C}$ clients. She used a purposeful sample of 60 hepatitis $\mathrm{C}$ clients of both sexes in the liver out client clinic at Shebin El-Kom teaching hospital and she found that the mean age of her studied group was $41.06 \pm 9.31$ years.

However; this result is lower than those of Heneedy, (2009) who conducted study entitled; the effect of nursing implementations on physical responses and compliance among clients with liver cirrhosis at the National Liver Institute and Menoufyia university hospital, and mentioned that the mean age of her study sample was $49.8 \pm 8.3$ for the study group. But this finding is not accordance with Younossi, (2008) who conducted study entitled; a phase II dose finding study of darbepoetin alpha and filgrastim for the management of anemia and neutropenia in chronic hepatitis $\mathrm{C}$ treatment and found that about two fifth of the studied sample were aged between 26 and 35 years old and only one fourth of the patients were aged between the ages of 46 and 55 years.
As regards to gender, the result of the present study showed that, more than half of studied patients were females, this could be due to most of caregivers for family members infected by any disease are the females specially the wives who dealing with their blood and body fluids infected with $\mathrm{HCV}$ without following infection control measures, this finding is in agreement with El lebodi, (2014) who conducted study entitled; outcome of acute hepatitis $\mathrm{C}$ infection in Egyptian patients and mentioned that more than two thirds of study group were females. but this finding is not in accordance with the results of Shata, ( 2014) who conducted study entitled; needs assessment of patients with chronic hepatitis $\mathrm{C}$ virus receiving combination therapy and found that more than three fourth of her studied group were male. Also the current finding is disagreement with Rizk, (2012) who conducted study entitled; assessment knowledge for patients with chronic hepatitis $\mathrm{C}$ receiving Interferon therapy and stated that more than two third of patients were male.

In relation to marital status, the results of this study revealed that most of the studied patients were married, this may be due to more than half of studied sample were at age $>45$ years, this finding is compatible with Abd El Rahman, (2018) who conducted study entitled; assessment knowledge, practice and satisfaction of clients with hepatitis C virus regarding Sovaldi therapy and reported that most of the sample were married, this finding might be due to the same age group of the studied sample.

Concerning educational level of the studied subjects, the results of the current study showed that more than half of the patients were secondary educated, while 
minority of them had completed university degree. This finding might be due to the majority of patients had low economic status which make them unable to face the cost of university education. This finding is supported by Rizk, (2012) who showed that more than one third of the patients were secondary, while minority of the sample had completed university degree.

Regarding Job, the results of this study revealed that half of studied patients work at governmental sectors, this could be due to their educational level and their age, this finding disagrees with Rizk, (2012) who found that about two fifths of studied sample did not work, also Khamis, (2017) who conducted study entitled; natural history of $\mathrm{HCV}$ in Egyptian patients, found that about two fifths of studied sample didn't work. The discrepancy between the finding of the current study and other studies could be related to the differences in the study sample.

Regarding residence, the results of this study revealed that, nearly three quarters of patients were from rural area, the possible explanation for the increase number of patients came from rural area may be due to lack of health care centers and patient's work as a farmer and liable for bilhareziasis infection. This finding is in agreement with Sarhan, (2011) who conducted study entitled; home health care program for patients with hepatitis $\mathrm{C}$ virus and their family members in kalyubia governorate and stated that majority of patients were from rural area, but this finding is contradicted with Abd El-Shahed, (2008) who conducted study entitled; factors affecting quality of life of patients with liver cirrhosis and reported that most of sample were from urban.

Regarding monthly income of the studied subjects, the results of this study represented that, more than two thirds of the studied patients had no enough monthly income to cover their needs in addition to costs of required periodical investigations to follow response of the treatment which add burden on the patients, this could be due to losses of income and low socioeconomic status for most Egyptian population, this is in agreement with Osman, (2016), who conducted study entitled; preventive measures taken by families living in contact with patients with infective hepatitis virus $\mathrm{C}$ in the rural community and reported that the majority of his subjects had low monthly income.

Respecting structure of liver, the finding of present study showed that more than two thirds of studied subjects had incorrect knowledge score, which is in agreement with Ibrahim, (2012) who conducted study entitled; assessment of health related behaviors among female patients with hepatitis $\mathrm{C}$ virus and found that most of whose study sample had incorrect answer regard structure of liver.

Regarding function of the liver, the finding of present study showed that most of studied subjects had incorrect knowledge score, this study finding is in accordance with Mahmoud, (2013) who conducted study about the impact of a self-care instructional program on quality of life of patients with liver cirrhosis at El kasr El-Ainy, Cairo university hospital, and mentioned that the highest percentage of the study subjects did not know the importance of the liver, also it is in line with Hussein, (2013) who conducted study about assessment of functional health status among patients with liver transplantation at Dar - El Fouad Hospital, and said that patients' knowledge about the 
importance of liver was not complete in the majority of the study sample.

Concerning meaning of hepatitis $\mathrm{C}$ virus, the finding of present study showed that more than half of the studied patients had incorrect knowledge score, this finding is inconsistent with Ali, (2015) who conducted study entitled; assessment factors affecting adherence of patients with viral hepatitis $\mathrm{C}$ toward therapeutic regimen and mentioned that approximately all the study subjects know what is HCV. Regarding types of HCV, the finding of present study showed that most of studied sample had incorrect knowledge about types of $\mathrm{HCV}$, this finding is congruent with Al-zafrany, (2013) who conducted study entitled; evaluation etiology and outcome of acute hepatitis $\mathrm{C}$ in different age group and stated that majority of study sample did not know types of HCV.

Pertaining meaning of acute hepatitis $\mathrm{C}$, the finding of present study showed that more than three quarters of studied subjects had incorrect knowledge score, this finding is in harmony with Al-zafrany, (2013) who mentioned that majority of study sample did not know meaning of acute HCV. Respecting causes of acute hepatitis $\mathrm{C}$, the finding of present study showed that more than half of studied subjects had incorrect knowledge about causes of acute hepatitis $\mathrm{C}$. This finding is inconsistent with El banna, (2016) who conducted study entitled; awareness of nonalcoholic fatty liver disease in Egyptian population and mentioned that half of study sample know causes of acute hepatitis $\mathrm{C}$.

In relation to high risk group of acute hepatitis $\mathrm{C}$, the finding of present study showed that more than half of studied subjects had correct knowledge score, this finding is in accordance with Abuamer, (2016) who conducted study entitled; descriptive analysis of possible causes of acute elevation in liver tests in patients with $\mathrm{HCV}$ - related chronic liver disease and mentioned that more than half of study sample had information about high risk group of acute hepatitis $\mathrm{C}$.

As regarding to mode of transmission, the finding of present study showed that nearly two thirds of studied subjects had incorrect knowledge score, this finding is supported by AlAian et al., ( 2006) who conducted study entitled; the prevalence of hepatitis $\mathrm{C}$ virus infection in the United States, and found that the majority of studied sample had unsatisfied knowledge score about mode of transmission, this could explain increasing prevalence of disease annually through formal and inform always of exposure to $\mathrm{HCV}$ infection in Egypt.

Pertaining sign and symptoms of disease, the finding of present study revealed that more than half of studied subjects had correct knowledge score, this finding is incompatible with Mohamed, (2011) who conducted study entitled; hepatitis C Virus (HCV) infection in a community in the Nile Delta: Population description and $\mathrm{HCV}$ prevalence and found that the majority of studied sample had unsatisfactory knowledge score about sign and symptoms of disease. This could be due to most of patients with acute hepatitis $\mathrm{C}$ infection are asymptomatic, if symptoms present varies from mild to moderate and severe.

Regarding diagnostic studies and periodical investigations to be done to confirm the diagnosis, the finding of present study revealed that more than half of studied subjects had correct knowledge score, this finding is contradicted with Kamal, (2008) who conducted study entitled; acute hepatitis 
C: A systematic review, and found that more than half of studied sample had unsatisfied knowledge score about diagnostic studies before treatment, also this finding is contradicted with El- Zanaty and way, (2009) who found that most of studied sample had unsatisfied knowledge score about diagnostic studies and periodical investigations.

As regards to prevention of $\mathrm{HCV}$, the finding of present study revealed that more than half of studied subjects had correct knowledge score. This finding is in accordance with Mahmoud, (2013) who mentioned that the majority of study sample knew the prevention of the disease. As regard to exercise to acute $\mathrm{HCV}$ patients, the finding of present study revealed that about two thirds of studied subjects had incorrect knowledge about this exercise, this result is agreed with Eldragini, (2016) who showed that most of whose studied sample had unsatisfactory knowledge score about exercise should be doing for HCV patients. This is due to lack of awareness of patients related to their level of education,

Respecting healthy nutrition and dietary modification for acute hepatitis $\mathrm{C}$ patients, the finding of present study revealed that more than half of the studied patients had incorrect knowledge score, this finding is in line with Elsayed, (2018) who conducted study entitled; assessment nutritional state in HCV chronic liver disease before and after treatment with direct acting antivirals therapy in Egyptian, and found that the majority of studied sample had unsatisfied knowledge score about nutrition of disease, this could be due to lack of health education from medical and nursing staff and lack of patients' awareness related to health instructions of nutrition. But this finding is in compatible with Baghdad, (2013) who mentioned that more than half of study sample gave the complete answer about healthy nutrition for the patients.

Belonging to healthy habits, the finding of present study revealed that nearly three quarters of studied subjects had correct knowledge score related to sexual intercourse. This finding is disagreed with Abass, (2013) who conducted study entitled; needs patient with chronic hepatitis $\mathrm{C}$ receiving antiviral therapy, suggested nursing, and stated that the majority of studied sample had unsatisfactory knowledge score about combination therapy, nutrition and sexual relation.

Regarding therapeutic regimen, the finding of present study revealed that three quarter of studied patients had correct knowledge score about name of the therapy, this finding is contradicted with Awad, (2016) who conducted study about quality of life of hepatitis $\mathrm{C}$ patients undergoing interferon therapy in Benha city, and mentioned that more than two thirds of clients had incorrect knowledge about meaning and types of sovaldi combination therapy. Concerning method of treatment, the finding of present study revealed that most of studied subjects had correct knowledge score. This finding is incompatible with El mesery, (2011) who conducted study entitled; failure of antiviral treatment in patients with chronic hepatitis $\mathrm{C}$, and found that most of his study sample did not know the method of treatment.

Concerning complications of acute $\mathrm{HCV}$, the finding of present study revealed that half of studied subjects had correct knowledge score, this finding is in accordance with Mohamed, (2011) who said that most of study sample knew the complications. Belonging to definition of liver cirrhosis, the 
finding of present study revealed that more than half of studied subjects had incorrect knowledge about the definition of liver cirrhosis. This finding is in line with Radhwan, (2016) who conducted study entitled the perceived learning needs of patients with hepatitis $\mathrm{C}$ to control associated health problems, and said that about two thirds of study sample did not know liver cirrhosis definition.

Pertaining to causes of liver cirrhosis, the finding of present study revealed that more than half of studied subjects had incorrect knowledge score, this finding is confirmed with AL-Metyazidy, (2014) who conducted study entitled effectiveness of a protocol of emergences nursing intervention on hepatic encephalopathy recurrence in patients with liver cirrhosis, and mentioned that most of study sample did not know the causes of liver cirrhosis, this is due to nearly three quarter of study sample were from rural area with less attention to acquisition health education and information about the potential complications of their disease.

Respecting signs and symptoms of liver cirrhosis, the finding of present study revealed that more than two thirds of studied subjects had incorrect knowledge score, this finding is supported by Al-Metyazidy, (2011) who conducted study entitled; effectiveness of nutritional support on clinical outcomes of patients suffering from liver cirrhosis, and state that the majority of studied sample gave incomplete answer about symptoms of liver cirrhosis.

Regarding prevention of liver cirrhosis, the finding of present study revealed that most of studied subjects had incorrect knowledge score, this finding is agreed with Abdelftah, (2012) who conducted study entitled; assessment nutritional status of patients with liver cirrhosis at Minia University Hospital, and found that the majority of study sample did not know how to prevent liver cirrhosis, this is due to less attention of patients to acquisition information about the complications of their disease and how to prevent it before occurrence, on another hand due to health team overload and also they neglect to provide the patients with health education and information needed.

Respecting meaning of liver cancer, the finding of present study revealed that about two thirds of studied subjects had incorrect knowledge score, this finding is consistence with Shaker, (2018) who conducted study entitled; a study of cyclase- associated plasma protein 2 as a novel biomarker for detection of hepatocellular carcinoma in HCV patients, and found that most of study sample gave incomplete answer about the definition of hepatocellular carcinoma. Regarding causes of liver cancer, the finding of present study revealed that more than two thirds of studied subjects had incorrect knowledge score about it. This finding is in line with Radhwan, (2016) who found that majority of study sample did not know the causes of liver cancer and said that learning needs of patients with hepatitis $\mathrm{C}$ should be acceded to control associated health problem and prevent any complication.

Concerning high risk factors for liver cancer, the finding of present study revealed that more than half of studied subjects had correct knowledge score, this finding is consistent with Abd El Rahman, (2012) who conducted retrospective study of different risk factors among patients of hepatocellular carcinoma in Bani- Suef governorate Egypt, and mentioned that two fifth of study sample did not know these factors. Pertaining to 
symptoms of liver cancer, the finding of present study revealed that more than two thirds of studied subjects had incorrect knowledge about these symptoms. This finding is in line with Ali, (2011) who conducted study entitled; assessment impact of hepatocellular carcinoma on health related quality of life and found that most of whose study sample gave incorrect answer about the question of the symptoms of liver cancer, this is due to lack of awareness of patients about their disease.

Belonging to prevention of liver cancer, the finding of present study revealed that about two thirds of studied subjects had incorrect knowledge score, this is confirmed by Abdel Hamid, (2016) who conducted study entitled; evaluation hepatocellular carcinoma vascular endothelial growth factor score for early detection of hepatocellular carcinoma among hepatitis $\mathrm{C}$ virus patients, and mentioned that most of whose study sample did not know how to prevent liver cancer. As regard to definition of liver failure, the finding of present study revealed that slightly more than half of studied subjects had incorrect knowledge score. This is not in line with Al- Sayed, (2012) who conduct study entitled; acute liver failure, and mentioned that more than half of his study sample knew the definition of liver failure.

Pertaining to causes of liver failure, the finding of present study revealed that two thirds of studied subjects had incorrect knowledge score. This finding is confirmed with Eid, (2016) who conducted study entitled; study of the precipitating factors of acute on chronic liver failure patients and found that more than half of his study sample did not know the causes of liver failure. Concerning signs and symptoms of liver failure, the finding of present study revealed that more than half of studied subjects had incorrect knowledge about these signs and symptoms. This finding is inconsistent with Muhammad, (2012) who conducted study entitled; etiology and outcome of acute liver failure in Zagazig University Hospitals, and said that half of his study sample knew these signs and symptoms and another half did not know.

Regarding prevention of liver failure, the finding of present study revealed that nearly two thirds of studied subjects had incorrect knowledge score. This finding is in accordance with Hassan, et al., (2011) who conducted study entitled; knowledge, attitude and lifestyle changes among chronic hepatitis C patients in Alexandria, Egypt: An earAppeal intervention, and found that most of study sample did not know how to prevent liver failure. In relation to extra hepatic complication, the finding of present study revealed that slightly more than three quarter of studied subjects had incorrect knowledge about these complications. This finding is confirmed with Ali, (2009) who conducted study entitled; outcome of hepatitis $\mathrm{C}$ virus infection community- based study and revealed that majority of his study sample did not know the extra hepatic complication.

Concerning the studied patients' total knowledge regarding $\mathrm{HCV}$ and self-care management, the finding of present study revealed that nearly two thirds of studied subjects had unsatisfied knowledge score, this might be due to majority of them were from rural area with less attention to acquisition of knowledge due to more than one third of them were only read and write and on another hand due to health team work overload which lead to lack of providing them with health education and information needed for more adaptation with their disease. 
This study finding is supported with Refaei, (2011) who conducted study entitled; knowledge, attitude and practice towards hepatitis $\mathrm{C}$ among patients and health care workers El Minia Governorate and found that majority of the studied sample had incorrect knowledge and emphasized that those patients with Liver diseases need education; counseling and support to enable them to adjust to their chronic illness and its treatment. This study finding is also consistent with Ghazy, (2018) who showed that most of the studied sample had incorrect knowledge score that required conduction of the nursing management protocol that indicates an improvement of patient's total mean score of knowledge.

Pertaining to practice of the studied patients regarding self-care management for complications prevention, the finding of present study revealed that more than half of studied subjects had adequate practice score regarding total self-care management components. More than half of them had adequate practice score related to their health habits, exercise/daily living activities and therapeutic regimen and follow up respectively, but more than two thirds of them had inadequate practice score related to healthy nutrition/ dietary modification components. This could be due to the difficulty of this issue.

This is supported by Ghazy, (2018) who found that more than half of her studied patients had moderate total practices score, more than one third of them had moderate self-care practices related social interactions and rest and sleep but the majority of them had poor self-care practice related to exercise and daily physical activity. Also this finding of present study is in line with Abd ElSalaam, (2016) who conducted study entitled; activities of daily living among patients with chronic hepatitis $\mathrm{C}$ virus, and state that the majority of sample achieved satisfactory score of life style practice and protection of others from spread of $\mathrm{HCV}$.

Concerning relation between the studied patients' total practice score regarding selfcare management and their demographic characteristics, the present study showed that there were statistically significant relations between the total practice score regarding self-care management and their marital status, educational level and gender. While there were no a statistically significant relation between their practice and the rest of demographic characteristics. This mean that demographic characteristics of the studied patients affected regarding positively on their practice score. These findings are going in line with Ali, (2015) who showed that there was statistical significant relation between the studied sample marital status, level of education, and their practice toward $\mathrm{HCV}$ while, there were statistical insignificant relation between gender, age, type of their work and their practice toward HCV.

Belonging to correlation between the studied patients' total knowledge and total practice regarding self-care management, the present study revealed that there was statistically significant correlation. This mean that the patients with satisfactory knowledge had adequate self-care management. This result agrees with Ghazy, (2018) who showed that there were very strong positive statistically significant correlation between total patients self-care practices and total patients knowledge level. 


\section{Conclusion:}

Based on the results of the present

study, the following can be concluded:

Nearly two thirds of the studied subjects had unsatisfactory knowledge score regarding $\mathrm{HCV}$ and self-care management for complications prevention. While more than half of them had adequate self-care management practice. There was no statistically significant relation between the studied subjects' total knowledge regarding $\mathrm{HCV}$ and self-care management and their socio demographic characteristics. However, there was statistically significant relation between the studied subjects' total practice regarding self-care management and their socio demographic characteristics; gender, marital status and educational level. There is a statistically significant correlation between the studied patients' total knowledge and their total practice regarding self-care management for complications prevention.

\section{Recommendations}

- The importance of developing of health education programs for acute $\mathrm{HCV}$ to improve their performance (knowledge\& practice) regarding self-care management.

- The essential of conducting regular counseling sessions for meeting the patients' needs regarding self-care management practice and solving their problems by providing them with clear, full and accurate information in both verbal and written form in health care settings as hospitals, clinic and so on ,in rural areas.

\section{References:}

Abass, A. (2013). Needs patient with chronic hepatitis $\mathrm{C}$ receiving antiviral therapy, thesis master, department of medical surgical nursing, Faculty of Nursing, Zagazig University, P. 44

Abdelftah, E. (2012). Assessment of nutritional status of patients with liver cirrhosis at MiniaUniversity Hospital,thesis master,department of medical surgical nursing, Faculty of Nursing, Assiut University,P. 79.

Abdel Hamid, M. (2016). Evaluation of hepatocellular carcinoma vascular endothelial growth factor score for early detection of hepatocellular carcinoma among hepatitis $\mathrm{C}$ virus patients, thesis master, department of hepatology, Faculty of medicine, Benha University. Pp. 54-60.

Abd El Rahman, A. (2012). Retrospective study of different risk factors among patients of hepatocellular carcinoma in Bani- Suef governorate Egypt, thesis master, department of internal medicine, Faculty of medicine, Bani- Suef Uni versity, P. 25.

Abd El Rahman, N. (2018). Knowledge, practice and satisfaction of clients with hepatitis C virus regarding Sovaldi therapy, thesis master, department of Community Health Nursing, Faculty of Nursing, Ain Shams University, Pp. 64-69.

Abd El-Shahed, B. (2008). Factors Affecting Quality of Life of Patients with Liver Cirrhosis, thesis master, department of Community Health Nursing, Faculty of Nursing, Ain Shames University. 59.

Abuamer, A. (2016). Descriptive analysis of possible causes of acute elevation in liver tests in patients with $\mathrm{HCV}$ - related chronic liver disease, thesis master, department of hepatology, National Liver Institute, Menoufiya University, P. 50. 
AlAian, G., Wasley, A., andSimard, E. (2006): The Prevalence of Hepatitis C Virus Infection in the United States, 1999 through 2002. Annals of Internal Medicine, 144: 705714.

Ali, M. (2009). Outcome of hepatitis C virus infection community- based study, thesis master, department of tropical medicine and gastroenterology, Faculty of medicine, Assiut University, pp. 90-94.

Ali, A. (2011). Assessment of impact of hepatocellular carcinoma on health related quality of life, thesis master, department of tropical medicine, Faculty of Medicine, Ain Shams University, P. 54.

Ali, S. (2015). Assessment of factors affecting adherence of patients with viral hepatitis $\mathrm{C}$ toward therapeutic regimen, thesis master, department of medical surgical nursing, Faculty of Nursing, Ain Shams University, Pp. 68-75.

Al-Metyazidy, A. (2011). Effectiveness of nutritional support on clinical outcomes of patients suffering from liver cirrhosis, thesis master, department of medical surgical nursing, Faculty of Nursing, Tanta University, PP. 18-22.

Al-Metyazidy, A. (2014). Effectiveness of a protocol of emergences nursing intervention on hepatic encephalopathy recurrence in patients with liver cirrhosis, thesis submitted for partial fulfillment of doctorate degree, department of medical surgical nursing, Faculty of Nursing, Tanta university, p. 4.

AL- Sayed, M. (2012). Acute liver failure, thesis master, department of Tropical medicine and Gastroenterology, Faculty of Medicine, Assiut University, P. 48.

Alzafrany, M. (2013).Evaluation of etiology and outcome of acute hepatitis $\mathrm{C}$ in different age group, thesis master, department of Internal Medicine, National Liver Institute, Menoufiya University, Pp.89-93.

Awad, A. (2016). Quality of life of hepatitis $\mathrm{C}$ patients undergoing interferon therapy in Benha City, thesis master, department of Community Health Nursing, Faculty of Nursing, Benha University, Pp. 28-33.

Baghdad, H. (2013).Impact of a designed supportive nursing program for hepatitis $\mathrm{C}$ patients on their functional health status during interferon therapy in the National Hepatology Medicine Research Institute, thesis master, department of Medical Surgical Nursing, Faculty of Nursing, Cairo University, Pp. 82-89.

Disease Control and Prevention.(2012). Progress toward prevention and control of hepatitis C virus infection. Egypt, 2001-2012. Morbidity and mortality weekly report weekly, 61,(29).pp.12-17.

Dorothea Orem's self-care theory. (2011). Nursing theory. Available at: http://currentnursing.Com/nursing_theory_selfcare_deficit_theory.html. Accessed on:11-2017

Eid, E. (2016). Study of the precipitating factors of acute on chronic liver failure patients, thesis submitted for partial fulfillment of doctorate degree, department of Internal medicine, Faculty of Medicine, Alexandria University, Pp. 43-44.

El banna, M. (2016). Awareness of nonalcoholic fatty liver disease in Egyptian population, thesis master, department of Gastroenterology and Hepatology, Faculty of medicine, Ain shams University, P.67.

Eldragini, M. (2016). Efficacy of combination therapy (Sofosbuvir, Pegylated Interferon and Ribavirin) in treatment of chronic hepatitis $\mathrm{C}$ in Egyptian patients, thesis 
master, department of Internal medicine, Faculty of Medicine, Ain Shams University, Pp. 67-70.

El Lebodi, M. (2014). Outcome of acute hepatitis $\mathrm{C}$ infection in Egyptian patients, thesis master, department of Internal Medicine, National Liver Institute, Menoufiya University, P. 79.

El-misery, A. (2011).Failure of antiviral treatment in patients with chronic hepatitis $\mathrm{C}$, thesis master, department of Tropical Medicine, Faculty of Medicine, Mansoura University, pp. 116-119.

Elsayed, A. (2018). Assessment of nutritional state in HCV chronic liver disease before and after treatment with direct acting antivirals therapy in Egyptian, thesis master, department of Internal Medicine, Faculty of Medicine, Ain Shams university. Pp. 51-53.

El-Zanaty F. and Way A. Egypt Demographic and Health Survey. (2009).Final Report, This study Completed the First Representative National Sample of HCV Antibody and HCV RNA. The Final Estimated Prevalence of HCV Antibody was 14.7\%. / El-Zanaty F, Way A. Ministry of Health. Pp. 430-450.

Ghazy, H. (2018). Factors associated with self care practices among patients with hepatitis $\mathrm{C}$ virus, thesis master, department of medical surgical nursing, Faculty of Nursing, Alexandria University, P. 54.

Hassan, S., EL-Ghitany, M., and El-sheikh, W. (2011). Knowledge, attitude and lifestyle changes among chronic hepatitis $\mathrm{C}$ patients in Alexandria, Egypt: An ear- Appeal intervention. Journal of American science, 8 (2), 9-73.

Heneedy, W. (2009): Study of The Effect of Nursing Intervention on Physical Responses and Compliance among Patients with Liver Cirrhosis at National Liver Institute and Menoufyia university hospital. Unpublished Doctoral Thesis.

Hussein, H. (2012): Assessment of functional health status among patients with liver transplantation at Dar - El fouad Hospital, thesis master, department of medical surgical Nursing, Faculty of Nursing, Cairo University, p. 116.

Ibrahim, H. (2012). Assessment of health related behaviors among female patients with hepatitis $\mathrm{C}$ virus, thesis master, department of medical surgical nursing, Faculty of Nursing, Alexandria University. PP. 13-17.

Kamal, S. (2008)."Acute Hepatitis C: A Systematic Review". The American Journal of Gastroenterology; 103 (5): 1283-97; quiz 1298.

Khamis, A. (2017). Natural history of HCV in Egyptian patients, Thesis master, Hepatology department, National Liver Institute, Menoufiya University, P. 87.

Mahmoud, F. (2013). The impact of a selfcare instructional program on quality of life of patients with liver cirrhosis at El kasr ElAiny, Cairo university hospital, thesis master, department of Tropical Medicine, Faculty of Medicine, Cairo university, Pp. 75-88.

Mohamed, M. (2011). Hepatitis C Virus (HCV) Infection in a Community in the Nile Delta: Population Description and $\mathrm{HCV}$ Prevalence. Hepatology, 32: 111-15.

Mohsen, A. (2009): Effect of Nursing Management Protocol in Selected Side Effect of Combination Therapy, Faculty of Medicine, Menofia University, Egypt.

Muhammad, A.S. (2012). Etiology and outcome of acute liver failure in Zagazig University Hospitals, thesis master, 
department of Internal Medicine, Faculty of Medicine, ZagazigUniversity, Pp. 75-81.

Nettleman, M.(2014). Hepatitis C symptoms, available at: www.emedicinehealth.com $>$ home $>$ infections center $>$ infections, accessed on: 10-10.

Osman, E. (2016). Preventive measures taken by families living in contact with patients with infective hepatitis virus $\mathrm{C}$ in the rural community, thesis master, department of Community Health Nursing, Faculty of Nursing, Ain Shams University, Pp. 86-89.

Papafragkakis, H., Rao, M., Moehlen, M., Dhillon, S., and Martin, P. (2012). Depression and Pegyylated Interferon_ based hepatitis $C$ treatment. International Journal of Interferon Cytokine and Mediator Research, 4, 25-35.

Radhwan, Z. ( 2016). The perceived learning needs of patients with hepatitis $\mathrm{C}$ to control associated health problems, thesis master,department of Community Health Nursing, Faculty of nursing, Menoufiya University, Pp. 54-57.

Refaei, S. (2011). Knowledge, Attitude and Practice towards hepatitis $\mathrm{C}$ among patients and health care workers El Minia governorate, thesis master, department of public health and preventive medicine, Faculty of medicine, Minia University,P.81.

Rizk, Sh. (2012). Assessment knowledge for patients with chronic hepatitis $\mathrm{C}$ receiving interferon therapy, thesis master, department of Medical Surgical Nursing, Faculty of Nursing, Benha University, Pp. 71-75.

Sarhan, A. (2011). Home health care program for patients with hepatitis $\mathrm{C}$ virus and their family members in Kalyubia governorate. thesis submitted for partial fulfillment of doctorate degree, department of Community Health Nursing, Faculty of Nursing, Banha University, P. 67.

Shaker, M. Y. (2018). A study of cyclaseassociated plasma protein 2 as a novel biomarker for detection of hepatocellular carcinoma in $\mathrm{HCV}$ patients, thesis master, department of internal medicine, Faculty of medicine, Ain Shams University, P.66.

Shata, Z. (2014).Needs assessment of patients with chronic hepatitis $\mathrm{C}$ virus receiving combination therapy, thesis master, department of medical surgical nursing, Faculty of Nursing, Ain Shams University, Pp. 72-75.

Smeltzer, S., and Bare, B. (2009). Brunner\& Siddhartha's Textbook of medical surgical nursing. $8^{\text {th }}$ ed. Philadelphia: J.B. Lippincott Company, India, p. 983.

Thomas, C. (2015). Hepatitis C: Transmission, symptoms, diagnosis \&treatment, available at: www.disabled_world.com > Health and disability $>$ hepatitis, accessed on: 23-8

Younossi, Z. (2008). A phase II dose finding study of darbepoetin alpha and filgrastim for the management of anaemia and neutropenia in chronic hepatitis $\mathrm{C}$ treatment. J Viral Hepatology, 15: 370-78. 
تقييم أداء مرضى التهاب الكبد الوبائي الحاد سي فيما يتعلق بادارة الرعاية الذاتية

\section{لمنع المضاعفات}

تحيه المحمدي محمودـ كاميليا فؤاد عبدالله - منال حامد محمودـ أمل سعيد طه

يعد فيروس التهاب الكبد الوبائي (سي) مشكلة صحية عامة مهمة في كل من الدول المتقدمة و النامية و على وجه التحديد مصر والتي تحتوي على أعلى نسبة انتشار من التهاب الكبد الوبائي في العالم. وهدفت هذه الدراسة الي تقييم أداء مرضى التهاب الكبد الوبائي الحاد فيما يتعلق بإدارة الرعاية الذاتية للوقاية من المضاعفات. وأجريت هذه الدر اسة في قسم الكبد بمستشفى بنها للحميات على عينة هادفة من 120 مريضا بالتهاب الكبد الوبائي الحاد وقد اظهرت هذه الدراسة أن أكثر من نصف الأشخاص الذين شملتهم الدراسة كان لديهم درجة معرفة غير مرضية ودرجة ممارسة كافية تتعلق بإدارة الرعاية الذاتية بالإضافة الى وجود علاقة ذات دلالة إحصائية بين ممارسة المرضى و البيانات الديمو غر افية الخاصة بهم متضمنة الحالة الاجتماعية و المستوى التعليمي و الجنس. وقد أوصت الدراسة بأهمية تصميم و تطوير برنامج تثقيفى صحي لمرضى التهاب الكبد الوبائي وعائلاتهم لتعليمهم كيفية تطبيق ممارسات إدارة الر عاية الذاتية للوقاية من المضاعفات. 